\title{
„LIBER CONSILIORUM” KONWENTU DOMINIKANÓW W POZNANIU**
}

\begin{abstract}
I
Klasztor dominikanów w Poznaniu należy do grona najstarszych fundacji Zakonu Kaznodziejskiego na ziemiach polskich, choć nieliczne i skąpe w wymowie źródła utrudniają odtworzenie jego początków. Możliwe, że bracia przebywali w położonej na prawym brzegu Warty osadzie Śródka już w latach 30-tych XIII wieku, choć regularny konwent uformował się w mieście zapewne nieco później, już po przeniesieniu poznańskiego centrum osadniczego na lewy brzeg Warty (do osady św. Gotarda) i jego lokacji na prawie niemieckim. We wskazanym przez Przemysła I i Bolesława Pobożnego miejscu dominikanie trwali przez następnych kilkaset lat, aż do zniesienia ich klasztoru przez władze pruskie w roku $1835^{1}$.

Tak długi okres funkcjonowania konwentu Braci Kaznodziejów na terenie Poznania znajduje odbicie w licznych źródłach dokumentujących jego dzieje. Największym zasobem archiwaliów po klasztorze św. Dominika dysponują obecnie dwie instytucje, to znaczy Archiwum Państwowe w Poznaniu oraz miejscowe Archiwum Archidiecezjalne. Zbiory materiałów podominikańskich w Archiwum Państwowym omówiła w kilku pracach Zofia Wojciechowska. Z poczynionych przez nią ustaleń wynika, że archiwalia po klasztorze św. Dominika są największym w ogóle zbiorem rękopisów poklasztornych przechowywanych w tej insty-

* Krzysztof Kaczmarek - dr hab. historii, prof UAM, kierownik Zakładu Historii Średniowiecznej Instytutu Historii UAM w Poznaniu.

${ }^{* *}$ Praca powstała w ramach projektu Narodowego Programu Rozwoju Humanistyki nr 11H11024180.

${ }^{1}$ Zwięzły zarys dziejów klasztoru w Poznaniu dał J.A. Spież, Dominikanie w Poznaniu, w: Poznańscy dominikanie, oprac. T. Dostatni, Poznań 1997, s. 5-18; zob. także tom studiów Nasi dominikanie, „Kronika Miasta Poznania”, 2004, nr 3; K. Kaczmarek, Konwent dominikanów poznańskich w okresie średniowiecza, „Ecclesia. Studia z Dziejów Wielkopolski”, 1 (2003) s. 35-54; ostatnio również T. Gałuszka, M. Zdanek, „Krakowskie” bulle rekomendacyjne Grzegorza IX a początki dominikanów polskich, „Studia Źródłoznawcze”, 44 (2006) s. 49-65.
\end{abstract}


tucji². Zbiór ten liczy 220 jednostek archiwalnych, wśród których znajduje się kilkadziesiąt dokumentów ${ }^{3}$, a także liczne (niekiedy bardzo obszerne co do objętości) księgi i akta klasztorne, w tym: niepublikowany dotąd nowożytny nekrolog, będący katalogiem zmarłych zakonników z Poznania i innych klasztorów prowincji w XVIII i XIX wieku ${ }^{4}$, dwa sumariusze dominikańskich dokumentów ${ }^{5}$, zapisy testamentowe na rzecz konwentu ${ }^{6}$, wypisy spraw dotyczących klasztoru wyjęte z różnych ksiąg sądowych ${ }^{7}$, wykazy kontraktów dzierżawnych należących do dominikanów nieruchomości ${ }^{8}$, a także będąca przedmiotem niniejszych uwag księga zawierająca protokoły z posiedzeń rady poznańskiego konwentu (liber consiliorum) z XVIII i XIX wieku?.

Dużo mniej wiadomo o manuskryptach podominikańskich przechowywanych w poznańskim Archiwum Archidiecezjalnym ${ }^{10}$. Warto poświęcić im w tym miejscu kilka słów, bowiem są to zabytki niezwykle interesujące (niektóre z nich można wręcz uznać za unikatowe w skali całej prowincji dominikańskiej), przy tym rzadko wykorzystywane przez historyków i w niewielkim stopniu wprowadzone do naukowego obiegu. Tę ostatnią uwagę łatwo zresztą zrozumieć, jeśli weźmiemy pod uwagę fakt, iż są to materiały ze stuleci XVII- XIX; wiadomo, że w przeciwieństwie do okresu średniowiecza ten fragment dziejów poznańskiego konwentu cieszy się znacznie mniejszym zainteresowaniem historyków. Poza znanymi skądinąd aktami nowożytnych kapituł polskiej prowincji dominikańskiej ${ }^{11}$,

${ }^{2} \mathrm{~W}$ tej sprawie. Z. Wojciechowska, Akta klasztoru dominikanów w Poznaniu, „Poznański Rocznik Archiwalno-Historyczny” (dalej: PRAH), 1 (1993) s. 41-51; taż, Akta klasztoru dominikanów w Poznaniu, „Archeion”, 93 (1994) s. 49-65; taż, Dokumenty i akta klasztorów w Archiwum Państwowym w Poznaniu - dzieje, zawartość i metoda opracowania, PRAH, 4 (1996) s. 57-72.

${ }^{3}$ Archiwum Państwowe w Poznaniu (dalej: APP), sygn. Dominikanie Poznań 1-71.

${ }^{4}$ Catalogus Mortuorum Conscriptus pro Conventu Formali Posnaniensi Anno Domini 1798, APP, sygn. Dominikanie Poznań 75.

${ }^{5}$ Kopiariusz dokumentów i przywilejów dla klasztoru dominikanów w Poznaniu z lat 12441643, APP, sygn. Dominikanie Poznań 72; Sumariusz dokumentów - nadań, zapisów, dzierżaw - dominikanów poznańskich z lat 1257-1772, APP, sygn. Dominikanie Poznań 73.

${ }^{6}$ APP, sygn. Dominikanie Poznań 78-98, 125-126 i 129-137.

${ }^{7}$ APP, sygn. Dominikanie Poznań 99-124, 127-128, 144-198.

${ }^{8}$ APP, sygn. Dominikanie Poznań 199-203.

${ }^{9}$ Liber Conciliorum Conventus Posnaniensis sub prioratu admodum reverendi prioris sacrae theologiae lectoris patris Candidi Nadaliński Anno Domini 1724 die 24 Ianuariii inchoatus, APP, sygn. Dominikanie Poznań 74 (dalej: LCCP).

${ }^{10}$ Zob. Archiwa Kościoła katolickiego w Polsce. Informator, oprac. M. Dębowska, Kielce 2002, s. 75-82, gdzie podstawowe wiadomości o jego zasobach.

11 Protokoły z posiedzeń najstarszych kapituł zostały wydane drukiem - zob. Acta Capitulorum Provinciae Poloniae Ordinis Praedicatorum, t. 1 (1225-1600), ed. R.F. Madura, Roma 1972; takie same protokoły z XVII-XIX wieku nie zostały dotąd opublikowane - zob. Acta Capitulorum Provinciae Poloniae Ordinis Praedicatorum, t. 2 (ab anno 1603 ad annum 1700 celebratorum), Biblioteka Studium Ojców Dominikanów w Krakowie (dalej: BSODK), sygn. 33429; Acta Capitulorum Provinciae Poloniae Ordinis Praedicatorum, t. 3 (a.1701-1800), BSODK, sygn. 33430; Acta Capitulorum Provinciae Poloniae Ordinis Praedicatorum, t. 4 (ab anno 1801-1863 ad annum 1920-1978), BSODK, sygn. 33431. 
w poznańskim Archiwum Archidiecezjalnym znajduje się bardzo bogata dokumentacja do nowożytnych dziejów poznańskiego Bractwa Różańcowego ${ }^{12}$, księga dochodów oraz wydatków konwentu z XVIII i XIX wieku ${ }^{13}$, a także jedna z nielicznych zachowanych do naszych czasów „Metryk profesów”- odnotowano w niej 849 braci, którzy złożyli zakonne śluby w poznańskim klasztorze św. Dominika w okresie od ostatniej ćwierci XVI stulecia aż do początku wieku XIX ${ }^{14}$. Dodajmy jeszcze, że we wskazanym Archiwum są także przechowywane równie mało znane, choć bardzo interesujące, materiały do dziejów innych klasztorów dominikańskich: po klasztorze w Kościanie zachowała się podobna do poznańskiej księga uchwał rady tamtejszego domu z XVIII wieku ${ }^{15}$, pochodzące z tego samego okresu księgi dochodów i wydatków konwentu ${ }^{16}$, wykazy zamówionych u dominikanów mszy ${ }^{17}$, a także spis osób ochrzczonych i pochowanych w kościele Braci Kaznodziejów w II połowie XVIII wieku ${ }^{18}$. Po klasztorze sieradzkim pozostał spisany w latach 30-tych XIX wieku i zawierający blisko 1900 pozycji wykaz ksiąg miejscowej biblioteki ${ }^{19}$. Poznańskie Archiwum Archidiecezjalne posiada także prawie nieobecną w naukowym obiegu XVIII-wieczną księgę uchwał rady konwentu w Sochaczewie ${ }^{20}$.

${ }^{12}$ Księga Arcybractwa Różańca św. 1631-1798, AAP, sygn. AZ 5/7; Liber Inscribendorum ad Archiconfraternitatem Sanctissimi Rosarii Beatae Virginis Mariae et Sororum Vivorum et Mortuorum restauratus 1689-1885; AAP, sygn. AZ 5/8; Księga Arcybractwa Różańcowego 1846-1893, AAP, sygn. AZ 5/10; Percepty i Expensy Bractwa Różańcowego 1779-1841, AAP, sygn. AZ 5/12; Księga Kasowa Bractwa Różańcowego - Niemców 1834-1840, AAP, sygn. AZ 5/13; Wykaz inwentarza znajdujacego się w kaplicy Bractwa Różańcowego przy kościele dominikanów 1839, AAP, sygn. AZ 5/14.

${ }^{13}$ Liber Regestrorum Proventis Conventu Posnaniensis Ordini Praedicatorum. Perceptae ab anno 1787 ad 1802 inclusive, expensae 1787-1803, AAP, sygn. AZ 5/11.

${ }^{14}$ Metrica Fratrum Professorum in Conventu Posnaniensi S. Dominici Ordinis Praedicatorum ab Anno Domini 1576 usque ad Annum 1815, AAP, sygn. AZ 5/6

${ }^{15}$ Liber Consiliarum Conventus Costensis Tempore Prioratus A.R.P Augustini Marcinkiewicz A.D. 1736 die prima Aprilis Comparatus, AAP, sygn. AZ 5/4.

${ }^{16}$ Księga kasowa dochodów (1766-1784) i rozchodów (1766-1785), AAP AZ 5/1; Księga kasowa dochodów i rozchodów 1753-1778, AAP, sygn. AZ 5/2.

${ }^{17}$ Liber tam missarum piercipiendarum [...] quam perceptarum bonorum 1764 sub prioratu A.R.P Antonii Kiciński, AAP, sygn. AZ 5/3.

${ }^{18}$ Liber actorum pro Conventu Costensis 1765; annoatio sepultorum in hoc Ecclesia et baptisatorum ab anno 1749 sub prioratu R.P. S.T.L. Petri Rogo, AAP, sygn. AZ 5/20.

${ }^{19}$ Katalog biblioteki klasztoru dominikanów w Sieradzu, AAP, sygn. AZ 5/18; na temat tego zabytku zob. J. Kosiński, Biblioteka konwentu dominikanów w Sieradzu na przełomie XVI i XVII wieku, w: Studia nad historią dominikanów w Polsce 1222-1972, t. 2, pod red. J. Kłoczowskiego, Warszawa 1975, s. 402 przyp. 21; ostatnio także G. Wierzchowski, Dzieje klasztoru dominikanów w Sieradzu od lat 30. XIII wieku do 1864 roku, Sieradz 2012, s. 30.

${ }^{20}$ Liber Consiliarum Conventus Sochacoviensis Ordinis Praedicatorum sub Felicissimo Regimine A.R. Patris Magistri Candidi Pilecki Prioris eiusdem conventus ex libris Antiquis Authenticis de novo conscriptus A.D. 1755, AAP, sygn. AZ 5/19; o ile mi wiadomo jak dotąd wykorzystał ją w badaniach tylko M. Skoczyński, Fundacja klasztoru dominikanów w Sochaczewie - stan badań i próba nowego spojrzenia, w: Między infuta, a korona - władza świecka i religia w średniowieczu, Wrocław 2012, s.127-143. 


\section{II}

W przeciwieństwie do konwentów należących do innych prowincji Zakonu Kaznodziejskiego, z których zachowały się księgi rad klasztornych jeszcze z okresu średniowiecza (przykładem może być choćby założona w połowie XV wieku księga domu w Bolonii) ${ }^{21}$, w spuściźnie archiwalnej polskiej prowincji dominikanów Libri Consiliorum są zabytkami późnymi i - zdaje się - dość rzadkimi. W latach 70-tych ubiegłego wieku wykaz tych ksiąg opublikował Robert Świętochowski. Autor ten podał, że zachowały się trzy tomy protokołów z posiedzeń rady prowincji (lata 1610-1627, 1631-1674 i 1793-1811), a także księgi zawierające sprawozdania z obrad „consiliów” klasztornych w: Borku Starym, Gidlach, Krakowie, Lwowie, Przemyślu, Tarnobrzegu, Sieradzu, Sochaczewie oraz Warszawie; ojciec Świętochowski wspominał także obecnie zaginioną (ale znaną jeszcze Sadokowi Barączowi) Liber Consiliorum klasztoru w Podkamieniu ${ }^{22}$. To wstępne zestawienie wkrótce udało się ojcu Świętochowskiemu poszerzyć o zabytki odnalezione w czasie kwerendy przeprowadzonej w archiwach litewskich, w których zlokalizował on protokoły z posiedzeń rad klasztorów w Ostrowcu, Rzeczycy oraz Wilnie ${ }^{23}$.

Porównianie zestawień sporządzonych przez R. Świętochowskiego z wcześniejszymi obserwacjami dotyczącymi rękopisów podominikańskich przechowywanych w archiwach poznańskich pokazuje, że wprowadzony przez tego autora do naukowego obiegu wykaz klasztornych Libri Consiliorum z terenu polskiej prowincji dominikańskiej nie był kompletny i można go łatwo powiększyć choćby o dwa wzmiankowane wyżej zabytki, to znaczy księgi z Kościana oraz Poznania. Trzeba również przywołać w tym miejscu nieobecną jak dotąd w naukowym obiegu księgę rady konwentu w Żninie z lat 1732-1815, przechowywaną w Archiwum Archidiecezjalnym w Gnieźnie ${ }^{24}$, a także podobny zabytek z klasztoru w Różanym Stoku w prowincji litewskiej, znajdujący się w zbiorach rękopiśmiennych Biblioteki Uniwersyteckiej w Wilnie ${ }^{25}$. Warto wreszcie wspomnieć o tym, że klasztorne Libri Consiliorum pisano także w domach żeńskich - przykładem takowej może być księga rady klasztoru dominikanek w Przemyślu z lat 1631-1782 należąca dziś do wrocławskiej Biblioteki Ossolineum ${ }^{26}$.

${ }^{21}$ Informację o niej podaję za M. Tavuzzim, Prieras: the life and work of Silvestro Mazzolini da Priero (1456-1527), Durham 1997.

${ }^{22}$ R. Świętochowski, Źródła do dziejów nowożytnych Zakonu Kaznodziejskiego, „Sprawozdania Towarzystwa Naukowego KUL” (dalej: STNKUL), 19 (1970, druk 1972) s. 87.

${ }^{23}$ Tenże, Podstawa źródlowa historii dominikanów w Polsce 1772-1970, STNKUL, 20 (1971), s. 83.

${ }^{24}$ Liber Conventus Znenensis Ordinis Praedicatorum 1732-1815, Archiwum Archidiecezjalne w Gnieźnie, sygn. Ap 39/167.

${ }^{25}$ Liber Consiliorum Conventus Rosastocensis Ordinis Praedicatorum, Biblioteka Uniwersytetu Wileńskiego. Dział Rękopisów, sygn. F 4 - A. 351 (za życzliwe wskazanie tego manuskryptu serdecznie dziękuję ojcu dr Sławomirowi Brzozeckiemu OP).

${ }^{26}$ Liber Consiliorum albo Xięga Rady Pospolitego, dobra y porządku klasztoru Panieńskiego de observantia Zakonu Dominika Świetego w Przemyślu 1631-1774, Biblioteka Zakładu Narodowego im. Ossolińskich, rkp. 5469/II. 
Zarówno sprawozdania z posiedzeń rad prowincji, jak i zapiski ze spotkań rad poszczególnych konwentów dominikańskich były (i nadal są) rzadko wykorzystywane przez historyków, mimo że już R. Świętochowski uważał te zabytki za „mózg działalności” tych instytucji ${ }^{27}$. Jerzy Kłoczowski odwołał się do protokołów z obrad „consilium” polskiej prowincji dominikańskiej i ksiąg rady krakowskiego klasztoru św. Trójcy w pracy o dziejach polskich dominikanów w XVII wieku $^{28}$. Niewiele także jest przykładów eksploatowania innych ksiąg rad klasztornych, co niewątpliwie trzeba uznać za pochodną słabego w ogóle zainteresowania dziejami konwentów dominikańskich w okresie potrydenckim. Na większą skalę wykorzystali klasztorne Libri Consiliorum badacze klasztoru w Sieradzu Paweł Migasiewicz uczynił to przy okazji rozważań nad budową i wyposażeniem tamtejszego kościoła Braci Kaznodziejów ${ }^{29}$, zaś Grzegorz Wierzchowski sięgnął do tego samego źródła podczas studiów nad nowożytną historią tego domu zakonnego $^{30}$. Ojciec Waldemar Kapeć korzystał z zawartości księgi rady klasztoru w Krakowie przy rekonstruowaniu życia muzycznego konwentu lubelskiego ${ }^{31}$, do materiałów tych sięgnęła także Anna Markiewicz przygotowując edycję „Kroniki fundacyjnej" dominikanek z klasztoru na krakowskim Gródku ${ }^{32}$. Józef Frazik wykorzystał informacje z Liber Consiliorum przy omawianiu nowożytnych dziejów kościoła dominikanów w Przemyślu ${ }^{33}$, zaś księga z Poznania została ostatnio uznana za ważne źródło dokumentujące funkcjonowanie szkół w konwencie św. Dominika w dobie nowożytnej ${ }^{34}$.

$\mathrm{Z}$ powyższych rozważań wolno wyciągnąć trzy istotne wnioski. 1/ O ile stan rozpoznania interesujących mnie zabytków znajdujących się w Archiwum Pol-

${ }^{27}$ Świętochowski, Źródła do dziejów nowożytnych Zakonu Kaznodziejskiego, s. 87.

${ }^{28}$ J. Kłoczowski, Wielki zakon XVII-wiecznej Rzeczypospolitej u progu swego rozwoju. Dominikanie polscy $w$ świetle wizytacji generalnej z lat 1617-1619, „Nasza Przeszłość”, 39 (1973) s. 103-180; ostatnio przedruk tej pracy w: tenże, Polska prowincja dominikańska $w$ sredniowieczu i Rzeczypospolitej Obojga (Wielu) Narodów, Poznań 2008, s. 363-430 (Studia nad historia dominikanów w Polsce, t. 5) - w kolejnych przypisach cytuję nowsze wydanie tej pracy.

${ }^{29}$ P. Migasiewicz, Kościót podominikański w Sieradzu, Warszawa-Sieradz 2003.

${ }^{30}$ G. Wierzchowski, Inwentarz folwarku Piaski z 1775 roku. Przyczynek do dziejów gospodarczych sieradzkich dominikanów w XVIII wieku, w: Dominikanie na ziemiach polskich w epoce nowożytnej, pod red. A. Markiewicz i M. Miławickiego, Kraków 2009, s. 469-484 (Studia i Źródta Dominikańskiego Instytutu Historycznego w Krakowie 5); tenże, Dzieje klasztoru dominikanów w Sieradzu, passim.

${ }^{31}$ W. Kapeć, Życie muzyczne w lubelskim klasztorze dominikanów, w: Dominikanie w Lublinie. Studia z dziejów i kultury, pod red. H. Gapskiego, Lublin 2006, s. 219-237.

${ }^{32}$ Kronika fundacyjna klasztoru mniszek Zakonu Kaznodziejskiego na Gródku w Krakowie (1620-1639), wstęp i opracowanie A. Markiewicz, Kraków 2007 (Studia i Źródła Dominikańskiego Instytutu Historycznego w Krakowie 3).

${ }_{33}$ J.T. Frazik, Kościót i klasztor dominikanów w Przemyślu, „Teka Komisji Architektury i Urbanistyki”, 19 (1995) s. 163-174; przedruk tej pracy w: Sztuka Przemyśla i Ziemi Przemyskiej. Zbiór studiów, red. M. Dłutek i J. Kowalczyk, Przemyśl 2004, s. 103-116.

${ }^{34} \mathrm{~K}$. Kaczmarek, Źródła do dziejów szkót dominikanów poznańskich w dobie nowożytnej, „Biuletyn Historii Wychowania”, 26 (2010, wyd. 2011) s. 59-68; tenże, Szkoły dominikanów poznańskich w XVI-XIX wieku, „Nasza Przeszłość”, 117 (2012) s. 229-243. 
skiej Prowincji Dominikanów w Krakowie za sprawą ustaleń R. Świętochowskiego wydaje się zadowalający, o tyle znajomość ksiąg rad dominikańskich klasztorów przechowywanych w innych archiwach jest daleka od doskonałości i zasadny wydaje się postulat przeprowadzenia wnikliwej kwerendy w celu stworzenia ich pełnego wykazu; 2/ Niemal wszystkie znane dziś klasztorne Libri Consiliorum $\mathrm{z}$ terenu polskiej prowincji dominikańskiej są zabytkami późnymi, pochodzącymi z XVIII wieku, a wyjątku od tej reguły wolno upatrywać chyba tylko w odniesieniu do klasztoru krakowskiego, bowiem najstarsze zachowane do naszych czasów księgi rady tego domu sięgają przełomu XVI i XVII wieku ${ }^{35}$. Nie znaczy to naturalnie, że w okresie wcześniejszym na terenie prowincji polskiej takich ksiąg nie prowadzono; ich istnienie jest więcej niż prawdopodobne, choćby $\mathrm{z}$ uwagi na wpisaną $\mathrm{w}$ system władzy funkcjonujący $\mathrm{w}$ zakonie dominikańskim zasadę kolegialności w podejmowaniu pewnych decyzji i konieczność odwoływania się przełożonych poszczególnych domów w różnych sprawach do opinii starszyzny konwentu. Mamy zresztą konkretne dowody na to, że zachowane do dziś w archiwach dominikańskie Libri Consiliorum miały swoje poprzedniczki. Na pierwszej stronie księgi klasztoru sochaczewskiego zachowała się na przykład adnotacja, która mówi, że została ona ex libris Antiquis Authenticis de novo conscriptus ${ }^{36}$, z czego jasno wynika, że musiała istnieć jakaś starsza wersja tamtejszej „księgi radzieckiej”. W aktach gospodarczych klasztoru poznańskiego z XVII wieku (a więc $\mathrm{z}$ okresu poprzedzającego powstanie księgi będącej przedmiotem niniejszych rozważań) odnajdujemy zaś informację o współdziałaniu przeora i rady we wspólnym przeprowadzaniu operacji finansowych konwentu - w roku 1699 Dominik Krzewiński, ówczesny przeor konwentu św. Dominika, za zgodą „ojców do rady należących" wypuścił w roczną dzierżawę należącą do zakonników wieś Buszewo ${ }^{37}$. Na pytanie, dlaczego współczesny historyk ma do dyspozycji niemal wyłącznie księgi z XVIII i XIX wieku nie ma jednoznacznej odpowiedzi. $\mathrm{Z}$ całą pewnością jednym z powodów takiego stanu rzeczy są ubytki w zasobach archiwalnych poszczególnych konwentów, powstałe w wyniku nawiedzajacych je katastrof w rodzaju pożarów, czy grabieży. Nie bez znaczenia było także zniszczenie i rozproszenie wielu archiwaliów w czasie kasat - pouczający wydaje się przypadek księgi ze Żnina, która (zanim pozyskało ją Archiwum Archidiecezjalne w Gnieźnie) była przechowywana w kościele parafialnym w Górze koło Żnina. Nie wykluczałbym także, że wpływ na niezły stan zachowania nowożytnych ksiąg radzieckich klasztorów dominikańskich miał również stanowczy wymóg staranności w prowadzeniu ich bieżącej dokumentacji oraz konieczności konsultowania przez przeorów podejmowanych przez nich decyzji z klasztorną starszyzną, narzucone dominikanom przez Damiana Fonsekę, wizytującego prowincję polską

${ }^{35}$ Zob. Primus Liber Consiliorum Conventus Cracoviensis SS-mae Trinitatis ab Anno Domini 1596 usque ad 14/VII, 1616, Archiwum Polskiej Prowincji OO. Dominikanów w Krakowie (dalej: APPDK), sygn. Kr 10; Consiliorum Patrum Cra. Ordinis Praedicatorum S. Trinitatis. Liber 2. Ab Anno 1615, APPDK, sygn. Kr 11.

${ }^{36}$ Liber Consiliarum Conventus Sochacoviensis, s. 1.

${ }^{37}$ Oryginały kontraktów dzierżawy wsi Buszewo różnym osobom, APP, sygn. Dominikanie Poznań 186, s. 1. 
w latach $1617-1619^{38} ; 3$ / Choć podane wyżej przykłady owoływania się przez współczesnych historyków zostały wybrane w przypadkowy sposób i zapewne dałoby się je nieco pomnożyć, to uzasadniony wydaje się pogląd, który mówi, że ten rodzaj źródeł znajduje się mimo wszystko na marginesie dominikańskiej historiografii. Taki stan rzeczy nie może satysfakcjonować historyków zajmujących się dziejami polskich dominikanów - prowincjalne i klasztorne libri consiliorum są przekazami o najwyższej wartości, zwłaszcza dla tego fragmentu dziejów polskiej prowincji dominikańskiej i poszczególnych klasztorów wchodzących w jej skład, który zawiera się między XVII i XIX stuleciem.

\section{III}

Liber Consiliorum dominikanów z Poznania zachowała się do naszych czasów w postaci oprawionego w brązową skórę kodeksu o wymiarach ok. 21,5×33,5 $\mathrm{cm}$. Liczy on 173 karty zapisane, a także kilkadziesiąt (dokładnie rzecz biorąc jest ich 36) kart pustych. Tekst źródła został spisany po łacinie; polskie wtręty zdarzają się, ale w ogólnej liczbie zapisek są bardzo rzadkie. Poznańska księga została zaprowadzona w dniu 24 stycznia 1724 roku i była używana przez zakonników niemal równo jeden wiek - ostatni protokół z obrad rady konwentu św. Dominika jest opatrzony datą 5 kwietnia 1822 roku $^{39}$. Można w tej sytuacji powiedzieć, że Liber Consiliorum poznańskiego klasztoru jest źródłem, które dokumentuje funkcjonowanie tego domu zakonnego w okresie ostatnich stu lat jego istnienia.

Wewnętrzna struktura księgi jest dopasowana do kadencji kierujących klasztorem przeorów, co widać po „incipitach” protokołów rozpoczynających rządy kolejnych przełożonych konwentu. Lektura księgi pokazuje, że we wskazanym wyżej przedziale czasu domem w Poznaniu rządziło w sumie 15 przeorów, z tym, że niektórzy z nich wykonywali swoje obowiązki więcej niż jedną kadencję. Kandyd Nadaliński, Berengar Rudzki i Piotr Rogo byli wybierani na stanowisko przeora trzykrotnie, po dwie kadencje na tym urzędzie spędzili: Felicjan Nowowiejski, Grzegorz Święciszkiewicz, Damian Konczalski i Mateusz Wolski, zaś pozostali (Stefan Skarszewski, Wojciech Borowicz, Jacek Tyski, Antoni Faberski, Alojzy Grajewski, Klemens Frasunkiewicz, Benedykt Herbowski oraz Florencjusz Bociański) wykonywali obowiązki przełożonych poznańskich dominikanów jeden raz. Co istotne, w klasztorze poznańskim bardzo skrupulatnie pilnowano tego, by funkcji przeora nie powierzać tej samej osobie kilka razy z rzędu. Od tej reguły odnajdujemy w księdze tylko jeden wyjątek - w latach 80-tych XVIII wieku (1781-1784 i 1784-1788) funkcję przeora w konwencie św. Dominika sprawował bez przerwy brat Mateusz Wolski.

Lektura protokołów wpisanych do zabytku pozwala bardzo precyzyjnie ustalić skład rady poznańskiego domu. Grono zakonników doradzających przeorowi w żywotnych dla dominikańskiej społeczności sprawach poznajemy dzięki ich własnoręcznym podpisom na protokołach z obrad consilium. Na przestrzeni niemal 100 lat skład rady - co naturalne - wiekorotnie się zmieniał, widać jednak,

\footnotetext{
${ }^{38}$ Kłoczowski, Wielki zakon, s. 418.

${ }^{39}$ LCCP, s. 337.
} 
że przy powoływaniu jej członków kierowano się bardzo konsekwentnie zasadą wprowadzania do niej braci wykonujących w obrębie klasztoru określone funkcje. Już w pierwszym protokole wpisanym do księgi pod datą 24 stycznia 1724 roku, a więc w momencie rozpoczęcia urzędowania na stanowisku przeora brata Kandyda Nadalińskiego, jako członkowie rady zostali wymienieni: przeor (Kandyd Nadaliński), magister teologii (Stefan Skarszewski), podprzeor (Jan Chwiralski), penitencjarz poznańskiej kapituły katedralnej (Tomasz Gwiazdowski), spowiednik konwentu (Ludwik Rybens), dwóch lektorów (Wojciech Balcerkowicz i Apolinary Bielowicz) oraz ówczesny mistrz nowicjatu (Wojciech Bilowicz) ${ }^{40}$. Niemal bez wyjątku wszystkie te osoby pojawiają się w charakterze członków rady także na pozostałych protokołach z jej obrad w dobie rządów przeora Kandyda Nadalińskiego, który - przypomnijmy - po raz pierwszy zarządzał konwentem poznańskim w latach 1724-1727. Zmiany jakie można zaobserwować w gronie starszyzny konwentu w tym okresie są nieliczne i obejmują pojedynczych zakonników: w roku 1724 Jana Chwiralskiego na stanowisku podprzeora zastąpił Rajmund Durski i natychmiast został włączony w skład consilium ${ }^{41}$, w tym samym roku jako „drugi lektor” konwentu w radzie zasiadał także brat Hieronim Szpytmański ${ }^{42}$, zaś od roku 1726 w miejsce Wojciecha Bilowicza w obradach uczestniczył lektor Wawrzyniec Poradowski ${ }^{43}$. Biorąc pod uwagę fakt, iż w zakreślonym wcześniej przedziale czasu obejmującym lata 1724-1727 rada odbyła w sumie 18 posiedzeń można powiedzieć, że jej skład odznaczał się daleko posuniętą stabilnością: należało do niej kilku (dokładniej rzecz biorąc 8) zakonników, pełniących kluczowe dla dominikańskiej społeczności funkcje, których wymieniano tylko wtedy, gdy owe funkcje pełnić przestawali i ustawał tym samym formalny powód dla ich zasiadania w consilium. Gdyby zestawić wykaz stanowisk, których zajmowanie otwierało drogę do zasiadania w radzie, należałoby wpisać nań funkcje: przeora (lub wikariusza konwentu), podprzeora, lektorów (liczba mnoga jest w tym miejscu zasadna, bowiem w Poznaniu było ich zwykle kilku) ${ }^{44}$, spowiedników (zarówno konwentu męskiego, jak i domu poznańskich dominikanek), mistrza nowicjatu, penitencjarza poznańskiej kapituły katedralnej, a także zakonników posiadających tytuły kaznodziei generalnego i doktora teologii (naturalnie, jeśli takowi w danym momencie przebywali w klasztorze); w skład rady wchodził także jej sekretarz, którego zadaniem było obliczanie wyników głosowań i sporządzanie protokołu z obrad.

Obserwacja ta prowadzi do kolejnego wniosku, który można wyciągnąć analizując wykazy osób należących do rady konwentu św. Dominika - zmiana na stanowisku przeora nie miała $\mathrm{w}$ zasadzie żadnego wpływu na to, kto wchodził w skład consilium. Zasadę tę łatwo uchwycić porównując ze sobą protokoły z końcowego okresu rządów ustępującego przeora i początków funkcjonowania jego następcy. Dla przykładu - brat Stefan Skarszewski, który objął kierownictwo

\footnotetext{
${ }^{40}$ Tamże, s. 7.

${ }^{41}$ Tamże, s. 10.

${ }^{42}$ Tamże.

${ }^{43}$ Tamże, s. 19 i n.

${ }^{44}$ Por. Kaczmarek, Szkoty dominikanów poznańskich w XVI-XIX wieku, passim.
} 
klasztoru w Poznaniu w roku 1727 po ustępującym Kandydzie Nadalińskim przez pierwsze dwa lata swojego urzędowania współpracował z niemal dokładnie taką samą radą, która doradzała jego poprzednikowi. Jedyną nową osobą, która zasiliła jej grono był brat Franciszek Pędziński, który w roku 1727 objął w Poznaniu stanowisko mistrza nowicjatu i jako taki z urzędu wszedł do rady ${ }^{45}$. Kolejny nowy członek consilium - kaznodzieja generalny Marcin Zachrowski - pojawił się zaś na jej obradach dopiero w roku $1729^{46}$. Kiedy w roku 1730 na stanowisko przeora wrócił Kandyd Nadaliński skład rady niemal się nie zmienił - jeszcze w roku $1731 \mathrm{z}$ racji posiadanych godności lub pełnionych funkcji w dalszym ciągu zasiadali w niej: Stefan Skarszewski (jako magister teologii), Rajmund Durski (jako podprzeor), Felicjan Nowowiejski i Wojciech Bilowicz (obaj jako lektorzy), a także Wawrzyniec Poradowski (spowiednik) i Marcin Zachrowski (kaznodzieja generalny $)^{47}$. Dwóch nowych członków rady, jakich spotykamy na protokołach z lat 30-tych XVIII wieku, zostało do niej włączonych z racji objęcia funkcji, z którymi łączyło się członkostwo w consilium: Michał Siejkowski zasiadł w niej z racji objęcia funkcji „drugiego lektora” konwentu, zaś Antoni Szynalski z uwagi na nominację na mistrza nowicjatu ${ }^{48}$. Podobnych przykładów wskazanego zjawiska można by naturalnie podać dużo więcej. Można w tej sytuacji uznać, że rada klasztoru poznańskich dominikanów była ciałem o stabilnym składzie, zaś fakt, iż jej członkowie nie pochodzili z nominacji przeora, tylko wchodzili do niej z urzędu, z uwagi na zajmowane w konwencie stanowiska, gwarantował jej dużą niezależność względem przełożonego klasztoru.

Lektura poznańskiej Liber Consiliorum pokazuje, że rada nie miała wyznaczonych stałych terminów posiedzeń. Byłoby o nie bardzo trudno z uwagi na charakter spraw, które wchodziły pod jej obrady - rozpatrywane przez nią kwestie miały najczęściej charakter doraźnych interwencji w życie klasztoru, w tym zwłaszcza w gospodarczą sferę jego funkcjonowania, a także w sprawy związane $\mathrm{z}$ jego obsadą kadrową. Biorąc pod uwagę fakt, iż owe interwencje podyktowane były koniecznością rozwiązania bieżących problemów, które trudno było przewidzieć, łatwo zrozumieć pewną przypadkowość w terminach spotkań członków rady. W pierwszej połowie XVIII stulecia ojcowie konwentu zbierali się na obradach najczęściej kilka razy do roku, zwykle (choć od tej reguły można znaleźć wyjątki) w odstępie kilku miesięcy. Dla przykładu - w roku 1724 rada zebrała się na obradach 6 razy, niemal taką samą częstotliwość jej spotkań (po $5 \mathrm{w}$ roku) da się ustalić dla lat 1725-1726. Za rząó́w Stefana Skarszewskiego (1727-1730) starszyzna konwentu obradowała nieco rzadziej - 2 lub 3 razy do roku. Zdarzyło się nawet (rok 1732), że spotkanie consilium zostało zwołane tylko 1 raz. Z zupełnie zaś wyjątkową sytuacją spotykamy się w roku 1735, kiedy nie odbyło się ani jedno posiedzenie rady. Zasadnicza, choć trudna do wythumaczenia, wymagająca dalszych analiz i badań porównawczych z innymi klasztorami, zmiana takiego stanu rzeczy nastąpiła w połowie lat 40-tych XVIII wieku, kiedy częstotliwość

\footnotetext{
${ }^{45}$ LCCP, s. 24.

46 Tamże, s. 26.

47 Tamże, s. 31.

${ }^{48}$ Tamże.
} 
spotkań rady wzrosła nagle i w sposób bardzo gwałtowny: w roku 1746 poznańskie consilium obradowało 11 razy, dwa lata później (1748 r.) takich spotkań odbyło się 16, w 1749 r. było ich 14, zaś w 1751 r. odbyło się 11 posiedzeń. Równie często rada spotykała się w latach 60-tych tego stulecia (1761 r. - 12, lata 1764 i $1765-13,1766$ r. - 14, 1767 r. - 15). Tendencja ta uległa wyraźnemu odwróceniu dopiero na początku XIX wieku, kiedy liczba posiedzeń zaczęła systematycznie spadać: w 1813 r. było ich 6, zaś w każdym następnym roku coraz mniej. W roku 1822, w którym kończą się zapiski w poznańskiej Liber Consiliorum, w klasztorze św. Dominika odbyło się tylko jedno posiedzenie rady konwentu. Dodajmy jeszcze, że widoczny w początkach XIX wieku spadek częstotliwości obrad rady szedł w parze z wyraźnym zmniejszeniem się jej liczebności - zamiast (jak to miało miejsce w XVIII stuleciu) 7-8 członków, w latach 20-tych XX wieku w obradach rady brało udział od 5-3 braci, co zapewne miało związek z malejącą w przededniu kasaty liczebnością całego konwentu.

Treść protokołów pozwala odtworzyć sposób, w jaki rada obradowała. Jej posiedzenia zwoływał przeor, lub (pod jego nieobecność, a także w okresie wakatu na tym stanowisku) wikariusz konwentu. Do kompetencji przeora należało także podanie porządku posiedzenia, to znaczy wskazanie spraw, które należało przedyskutować i ustalenie kolejności ich rozpatrywania. Wykaz problemów, jakie rozwiązywano na jednym posiedzeniu nie był specjalnie rozbudowany i obejmował zwykle od 2 do 4 punktów, choć zdarzały się i takie posiedzenia, na których omawiano i głosowano tylko jedną sprawę. Nie dziwi w tej sytuacji, że protokoły z obrad poznańskiego consilium są z najczęściej krótkie i zwięzłe w treści; wyjątku od tej reguły wolno upatrywać wyłącznie w sprawozdaniach z tych posiedzeń, na których rozwiązywano skomplikowane sprawy gospodarcze. Te ostatnie były omawiane bardzo dokładnie - przeor informował radę o wszystkich szczegółach planowanych transakcji, dotyczących (na przykład) dzierżawy klasztornych wsi i sum czynszu, jakie przewidywał uzyskać z tego tytułu, czy też warunków pozyskiwania bardzo w tym okresie licznych zapisów testamentowych na rzecz konwentu.

W przeciwieństwie do zwyczajów współczesnych, w protokołach z posiedzeń rady poznańskich dominikanów z zasady nie notowano przebiegu dyskusji, jaka bez wątpienia musiała towarzyszyć obradom. Nie wiemy więc, którzy z członków consilium zabierali głos na posiedzeniach i jaka była treść ich wystąpień. Wiadomo natomiast, że każdy z omawianych punktów był poddawany osobnemu głosowaniu. Technika samego głosowania i rozkład głosów niezostały odnotowane w protokołach. Stwierdzano w nich zwykle, że na przedstawione jej przez przeora zapytanie w konkretnej sprawie rada odpowiedziała twierdząco (responderunt affirmative). W niektórych protokołach podkreślono, że w rozstrzyganiu jakiejś kwestii członkowie rady zachowali jednomyślność, ale zważywszy na fakt, iż takie sytuacje zdarzały się stosunkowo rzadko, trzeba przyjąć, że w rozwiązywaniu przedstawianych jej problemów rada decydowała zwykle większością głosów. Niekiedy rezultat głosowania był negatywny. Do takich sytuacji dochodziło podczas głosowań nad dopuszczaniem zakonników do profesji - zdarzało się, że ojcowie klasztoru podnosili, iż dana osoba nie jest jeszcze gotowa do złożenia ślu- 
bów i decydowali o odroczeniu profesji na jakiś czas, po to, by zainteresowany zakonnik mogł się do niej lepiej przygotować. Dodajmy jednak od razu, że takie sytuacje zdarzały się bardzo rzadko - w całej księdze udało mi się odnaleźć tylko dwa takie przypadki. W dniu 11 lipca 1783 roku do poznańskiego nowicjatu został przyjęty Onufry Żmudowicz (później używał zakonnego imienia Jakub) ${ }^{49}$. Kiedy jednak jego próba miała się ku końcowi, na posiedzeniu 18 maja 1784 roku rada konwentu stwierdziła, że Jakub stanął nieprzygotowany do egzaminu poprzedzającego profesję i z tego powodu odłożyła złożenie przezeń ślubów o dwa miesią$\mathrm{ce}^{50}$. Po raz kolejny zakonnik został do nich dopuszczony (już z dobrym skutkiem) w dniu 19 lipca 1784 roku $^{51}$. W tym samym dniu co Onufry (Jakub) Żmudowicz, do nowicjatu przyjęto również Grzegorza Łapińskiego, który po wstąpieniu do klasztoru przybrał zakonne imię Czesław ${ }^{52}$. On także do egzaminu poprzedzajacego profesję stanął nieprzygotowany i musiał odczekać dwa miesiące zanim dano mu kolejną szansę, którą zresztą wykorzystał ${ }^{53}$.

Przedmiotem zainteresowania rady były przede wszystkim sprawy o charakterze osobowym. Rozpatrywane przez poznańskie consilium kwestie personalne dotyczyły: powoływania komisji odpytującej kandydatów do nowicjatu, wydawania formalnej zgody na rozpoczęcie próby w nowicjacie przez osoby, które uzyskały pozytywną rekomendację owej komisji, zezwoleń na złożenie przez nowicjuszy profesji, a także licencji na przystępowanie zakonników do poszczególnych stopni święceń. Do kompetencji rady należało także mianowania klasztornych urzędników, w tym: podprzeorów, prokuratorów, syndyków, depozytariuszy, bursariuszy, bibliotekarzy, zakrystianów, sekretarzy rady oraz mistrzów nowicjatu. Analiza poszczególnych protokołów pozwala uchwycić funkcjonującą w konwencie prawidłowość w obsadzaniu klasztornych urzędów - do zmian na poszczególnych stanowiskach dochodziło albo z przyczyn naturalnych (śmierć zakonnika, zakończenie kadencji, w której wykonywał on swoje obowiązki), albo z powodów nadzwyczajnych, związanych z dobrowolną rezygnacją z pełnionego urzędu oraz przeniesieniem funkcyjnego profesa do innego klasztoru. Należy przy tym podkreślić, że wśród wszystkich spraw rozpatrywanych przez radę, to właśnie kwestie osobowe stanowią największą co do liczby kategorię zapisek w księdze radzieckiej. Z tego powodu poznańską Liber Consiliorum należy uznać za źródło o pierwszorzędnej wartości dla badań nad składem osobowym konwentu św. Dominika i jego wewnętrzną strukturą w dobie nowożytnej.

Przedmiotem zainteresowania starszyzny konwentu były także gospodarcze podstawy utrzymania klasztoru. Już na pierwszym posiedzeniu, którego protokół został wpisany do księgi, ojcowie zasiadający w radzie przypomnieli wprowadzonemu właśnie na urząd przeora Kandydowi Nadalińskiemu, aby ten przez pamięć na zakonne konstytucje nie ważył się zawierać żadnych umów w imieniu konwen-

\footnotetext{
49 Tamże, s. 238.

50 Tamże, s. 243.

51 Tamże, s. 245.

52 Tamże, s. 238.

53 Tamże, s. 243 i 245.
} 
tu sine majoris partis patrum de consilio consensu et subscriptione ${ }^{54}$. O tym, że rada stanowczo egzekwowała swoje uprawnienia do kontrolowania dochodów i wydatków konwentu świadczą nie tylko liczne sprawy o takim właśnie charakterze trafiające bezpośrenio pod jej obrady, ale i widoczny udział consilium w bezpośrednim zawieraniu przez klasztor różnych umów gospodarczych. Przykłady można by mnożyć, więc wyłącznie w celu udokumentowania powyższego twierdzenia odwołamy się w tym miejscu do bardzo obszernej, zachowanej w poznańskim Archiwum Państwowym, dokumentacji, która dotyczy należącej do poznańskich dominikanów wsi Buszewo. W roku 1737 przeor Felicjan Nowowiejski za zgodą „ojców do rady należących” puścił wspomnianą wieś w trzyletnią dzierżawę Maciejowi i Róży Skuraszewskim za sumę rocznego czynszu opiewającą na 1000 złotych polskich ${ }^{55}$; kilka lat później (1744 r.) podobną operację, też za zgodą rady, przeprowadził przeor Kandyd Nadaliński ${ }^{56}$. Bodaj najwięcej spraw o charakterze ekonomicznym, jakie rozpatrywała rada dotyczyło zapisów testamentowych i donacji na rzecz klasztoru i wynikających z nich zobowiazań braci do zachowania pamięci o zmarłych dobrodziejów klasztoru. Dla przykładu - w protokole z obrad consilium w dniu 2 sierpnia 1743 r. rada zatwierdziła umowę z Barbarą Winklerową, która darowała klasztorowi sumę 50 florenów węgierskich w zamian za odprawianie anniwersarzy za swych zmarłych rodziców (Jana i Katarzynę) $)^{57}$, zaś w roku 1760 starszyzna konwentu przyjęła donację wieczystą w kwocie 2 tysięcy uczynioną przez Wiktorię Węgorzewską, obwarowaną żądaniem odprawiania w jej intencji mszy przed otłarzem Krzyża św ${ }^{58}$.

Wszystkie postanowienia podjęte przez radę, zarówno te w sprawach osobowych, jak i te o charakterze ekonomicznym, były przedstawiane do zatwierdzenia władzom prowincji. Czasami o takie zatwierdzenie było bardzo łatwo, bowiem zdarzało się (choć rzadko), że prowincjał osobiście uczestniczył w obradach starszyzny poznańskiego konwentu. Jeśli jednak trzeba było ksiegę uchwał dostarczyć mu do wglądu i zatwierdzenia podjętych przez radę decyzji, to oczywiste jest, że taka procedura wymagała czasu. Stąd zapewne prowincjałowie nie potwierdzali wszystkich kolejno podejmowanych przez radę decyzji, tylko czynili to co jakiś czas, zwykle w odstępie kilku miesięcy, a nawet (takich przypadków jest jednak znacznie mniej) kilku lat. Co ciekawe, osobiste „,widematy” prowincjałów pod uchwałami poznańskiego consilium, wcale częste w pierwszej połowie XVIII wieku, w drugiej części tego stulecia stają się coraz rzadsze - z tego okresu w księdze odnajdujemy wyłącznie podpisy Berengara Rudzkiego z lat 1759 i $1761^{59}$, Brunona Bogatko (lata 1763 i 1765) ${ }^{60}$ oraz Bazylego Barskiego z $1766 \mathrm{r}^{61}$. Ostatni zatwierdzenie uchwał poznańskiego consilium przez prowincjała Marcina Ruciń-

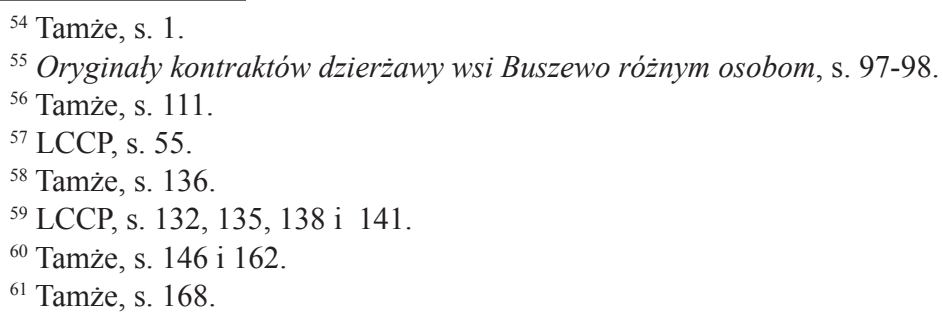


skiego miało miejsce w dniu 13 września $1769 \mathrm{r}^{62}$. Możliwe, że widoczne trudności w pozyskiwaniu potwierdzeń postanowień poznańskiej rady przez prowincjałów pod koniec XVIII wieku były efektem ograniczeń w podróżowaniu, jakie zaborcy narzucili dominikanom po roku 1772 .

W świetle powyższych rozważań widoczne są dwa obszary badań nad nowożytnymi dziejami klasztoru dominikanów w Poznaniu, w których przedstawiona pokrótce zawartość tamtejszej „księgi radzieckiej” ma pierwszorzędne znaczenie. Pierwszym z nich są badania prozopograficzne - dokładna analiza polityki, jaką w sprawach kadrowych prowadziła rada konwentu św. Dominika, wsparta znajomością innych źródeł obrazujących tą sferę funkcjonowania poznańskiego zespołu Braci Kaznodziejów, w tym zwłaszcza wspomnianej wcześniej „Metryki profesów", może w przyszłości owocować cennymi studiami ukazującymi stan osobowy klasztoru w dobie nowożytnej i rolę poszczególnych profesów w jego zarządzaniu. Postanowienia podejmowane na posiedzeniach poznańskiego consilium zachowują także kluczowe znaczenie dla odtworzenia materialnych podstaw funkcjonowania klasztoru św. Dominika w XVIII i początkach XIX wieku. Pozostaje w tej sytuacji mieć nadzieję, że w niedalekiej przyszłości historycy zajmujący się dziejami życia zakonnego w Poznaniu przeprowadzą takie badania i zlikwidują tym samym dotkliwą lukę dotychczasowej w znajomości nowożytnych dziejów tamtejszej wspólnoty Braci Kaznodziejów.

\section{„LIBER CONSILIORUM” OF DOMINICAN CONVENT IN POZNAN.}

\section{Summary}

The purpose of this study has been to introduce the hitherto absent documentary proof - Liber Consiliorum of the Dominican Convent in Poznań - into the scientific workflow and to preliminarily analyse the internal structure and content of this historic writing. The author has touched upon this subject, believing that Dominican „Soviet Books” are of greatest significance for understanding internal mechanisms of operations of the Friars Preachers Monastery in the contemporary world, and indirectly the operations of the Polish Dominican Province as a whole in that time interval. The Book of Poznan came to existence in January 1724 and was maintained until 1822. It is plausible to state that it is the documentary proof for the operations of Saint Dominic's Convent in the period - more or less - of the last hundred years of its existence. The content of the Book has its primary significance for the research on the head-count of the Convent in 18th Century and at the beginning of 19th Century. It is also difficult to overestimate the importance of its content from the point of view of the studies on the modern administration of the Convent in Poznan. The comprehensive study on the content of other books of councils of Saint Dominic's Convents in the post-Tridentine Era, as preserved in archive collections, would certainly facilitate to understand the mechanisms of the Convents' operations and would expand the knowledge on their human resources to a great extent.

${ }^{62}$ Tamże, s. 183. 